Bond University

Research Repository

\title{
Psychoanalysis and Film
}

Cox, Damian; Levine, Michael P.

Published in:

The Oxford Handbook of Philosophy and Psychoanalysis

DOI:

10.1093/oxfordhb/9780198789703.013.31

Licence:

Other

Link to output in Bond University research repository.

Recommended citation(APA):

Cox, D., \& Levine, M. P. (2019). Psychoanalysis and Film. In R. Gipps, \& M. Lacewing (Eds.), The Oxford Handbook of Philosophy and Psychoanalysis (pp. 513-530). Oxford University Press.

https://doi.org/10.1093/oxfordhb/9780198789703.013.31

\section{General rights}

Copyright and moral rights for the publications made accessible in the public portal are retained by the authors and/or other copyright owners and it is a condition of accessing publications that users recognise and abide by the legal requirements associated with these rights.

For more information, or if you believe that this document breaches copyright, please contact the Bond University research repository coordinator. 


\section{Psychoanalysis and Film}

Damian Cox and Michael Levine

\section{Abstract: Psychoanalysis and Film}

Those who believe that the psychoanalytic understanding of human nature is broadly correct will also likely believe that there are essential aspects of film that cannot be adequately understood without it. Among these are (i) film's power; (ii) the nature of film spectatorship; and (iii) the characteristics of specific films and genres. Why are we attracted to certain kinds of films--horror films and those depicting violence we abhor? The most basic claim underlying psychoanalytic approaches to film is that the creation and experience of film is driven by desire and wish-fulfilment and functions to satisfy certain psychological, protective, expressive needs of artists and audiences. Psychoanalytic explorations of film tend to draw together aspects of artistic creation and spectatorship, as well as accounts of film's power to move audiences and the nature of film spectatorship in general--the affective and cognitive significance of the nature of film experience itself.

\section{Keywords}

spectatorship

power

horror

wish-fulfilment

desire

violence

affective and cognitive significance

protective and expressive needs

human nature

experience

\section{Introduction}

Psychoanalysis is both a set of theories of the structure and workings of the mind and the

psychotherapeutic method based on Freud's theory of the mind. Those who believe that the

psychoanalytic understanding of human nature and the mind are broadly correct will also likely

believe that there are essential aspects of film that cannot be adequately understood without it. ${ }^{1}$

\footnotetext{
${ }^{1}$ Freud, however, was not an enthusiast. Gabbard (2001: 1-2) claims that "The cinema and psychoanalysis have a natural affinity." But he goes on to say that "The marriage between movies and psychoanalysis occurred in spite of Sigmund Freud. As far as we know, Freud had little regard for the cinema as an art form and appeared almost oblivious to the development of movies during his lifetime (Sklarew, 1999). His attitude was perhaps best illustrated when Hollywood producer Samuel Goldwyn offered him a $\$ 100,000$ fee to consult on a film he was planning to shoot in 1925. Freud rejected the offer without a second thought. The New York
} 
Prominent among these are (i) film's power; (ii) the nature of film spectatorship; and (iii) the characteristics of specific films and genres. Why are we attracted to certain kinds of films, for example horror films and those depicting violence we abhor? ${ }^{2}$ Psychoanalytic approaches to film tend to be more unified than piecemeal approaches that see issues of spectatorship and narrative construction and genre as discrete questions. However, the fact that psychoanalysis approaches film with a unified theory of mind, though there is considerable dispute as to its details, should not be confused with the claim that psychoanalytic approaches are exhaustive and complete.

Richard Allen (2009: 446) says "Orthodox psychoanalytic theories of art have focused on [1] the relationship between the creation of art, sexuality, and unconscious mental life, and a great deal of both film and literary criticism has used psychoanalytic theory to interpret texts or genres of texts, but the distinctive contribution of film theory to psychoanalytic theories of art lies in [2] its focus upon the nature and character of film spectatorship." From a psychoanalytic perspective 1 and 2 are closely related. Freud sought to explain not just the meaning of texts and their relation to the artist-what the artist is doing and how art functions both for artists and audiences. He also sought to explain why audiences took an interest in such works, and how and why art is able to convey phantasies, wishes and desires in ways palatable to audiences. ${ }^{3}$ The most basic claim underlying psychoanalytic approaches to film is that the creation and experience of film is driven by desire and wish-fulfilment and functions so as to satisfy certain psychological, protective, expressive needs of both artists and audiences.

Psychoanalytic explorations of film tend to draw together aspects of artistic creation and spectatorship. The conditions of a work's creation and the ways in which it is viewed are connected, though not identical. Psychoanalytic explorations of film also tend to draw

Times of 24 January 1925 displayed the following headline: 'Freud Rebuffs Goldwin: Viennese Psychoanalyst Is Not Interested in Motion Picture Offer (Sklarew, 1999, p.1244)."

${ }^{2}$ Tudor (1997:444) distinguishes between the following two questions. "What is it about people who like horror?' and 'what is it about horror that people like?"' Psychoanalytically-speaking, however, these are just two sides of the same coin.

${ }^{3}$ Levine (2015). 
together accounts of film's power to move audiences and the nature of film spectatorship in general (the affective and cognitive significance of the nature of film experience itself). They also tend to draw together accounts of films' power to move audiences and the characteristics of particular genres of films - such as horror films or revenge films.

When it comes to film theory, psychoanalytic influence has been profound. Christian Metz's Lacanian account of film spectatorship and Laura Mulvey's account of the structure of cinema as grounded in male voyeurism are two very prominent and influential psychoanalytic interventions in film theory, but the interactions between the two fields has been longstanding, extensive, varied and deep. ${ }^{4}$ In the late 1980s, however, a group of film theorists overtly hostile to psychoanalytic ways of approaching film came to prominence. Film studies undertook a cognitivist turn; and one of the foundational cruxes of cognitivism was a rejection of the psychoanalytic modes of explanation. ${ }^{5}$ Cognitivists in film theory attempt to explain basic features of film experience: audience comprehension, emotional elicitation, character identification and aesthetic preference. ${ }^{6}$ They do so using the resources of contemporary cognitive science and analytic philosophy, self-consciously eschewing the work of psychoanalytic theorists. They represent the most trenchant critics of psychoanalytic approaches to the study of film. In our view, the rejection was premature and exaggerated. We discuss cognitivism and its rejection of psychoanalytic approaches to film later in the chapter. But first we offer a clarification of applications of psychoanalysis. We then explore the positive side of the story. What relevance might psychoanalysis have to the creation and experience of film art?

\footnotetext{
${ }^{4}$ Metz (1982); Mulvey (1989). Other examples include: Baudry (1986a); Clover (1992); Copjec (1989); Creed (1993); Rodowick (1991); Schneider (2000); Studlar (1988); Žižek (1992).

${ }^{5}$ The publication of David Bordwell's Narration in the Fiction Film (1985) is the founding moment of the cognitivist turn in film theory. The pervasiveness of cognitivist criticism of psychanalytic approaches to film is on display in such places as the Routledge Companion to Philosophy and Film (2009). The entry on psychoanalysis in this work, by Richard Allen, is robustly critical and sometimes dismissive. We discuss Allen's views below.

${ }^{6}$ Prominent cognitivists in film studies include Bordwell (1985), Carroll (1996), Currie (1995), Plantinga (2009), Smith (1995).
} 


\section{Applying Psychoanalysis to Film}

Psychoanalytic aesthetics has drawn from and contributed to psychoanalytic theory. Freud and psychoanalytic theorists generally have seen art as supporting and enlarging such theory. For those who accept the basic tenets of psychoanalysis, its engagement with aesthetics has advanced theory by enhancing the psychoanalytic understandings of mind and human nature. ${ }^{7}$ Basic tenets of psychoanalysis that are especially relevant in this context include such things as the reality of dynamic unconsciousness, the reality of 'primitive' (primary process) mental function focussed on immediate gratification of instincts and drives, the centrality of defense mechanisms for managing anxiety, the emotional meaningfulness of dreams and phantasy. Some features of film spectatorship are best explained by our tendency to repress and disavow uncomfortable or perverse desires, and to gain a special kind of gratification from the vicarious satisfaction of these desires in dreams and phantasies. In dreams and phantasies, representations beset us and our ordinary modes of selfcritical judgment are suspended. Much the same thing seems to happen, at least sometimes, in film spectatorship.

Much as Freud used what he termed "the psychopathology of everyday life," film and other arts are used to support the validity of psychoanalysis and to theoretically enhance it. ${ }^{8} \mathrm{An}$ understanding of art on the one hand and psychoanalysis on the other is mutually supportive. An understanding of both art and psychoanalysis is furthered by explaining fundamental features of aesthetics: its significance in virtue of the roles that it plays in our lives; the relation between artists and their work, as well as between artists and audiences; and even why there is any art all.

\footnotetext{
${ }^{7}$ See Damien Freeman, "On Richard Wollheim's psychoanalytically informed philosophy of art," and Elisa Glagut, "Literary Form and Mentalization" both in this volume. Also see Kemp \& Mras (2016); Levine (2016).

${ }^{8}$ See Sterba (1940, p. 257): “The ... complemental relationship between the two sources of information consists then in the theoretical enlightenment about art and the artist to be found in papers devoted to the psychoanalytic theory of neurosis, while in those papers devoted to an examination of specific objects of art and artists we are given insight into more general analytic theories and methods."
} 
It is a common misconception of psychoanalytic approaches to film and art generally to think that if there are exceptions to Freud's claim that art is driven by desire and wish-fulfilment, and functions to satisfy certain psychological, protective, expressive (or whatever) needs of artists and audiences, then one will have shown Freud's views about art to be mistaken. ${ }^{9}$ Clearly, exceptions undermine claims of universal and necessary truth, but psychoanalytic approaches to film need not make such claims. Wood (2004: xv) expresses the point this way.

Part of the problem lies in that distressingly common tendency either to totally accept or totally reject, as opposed to the principle of examining critically. Few today appear to read Freud or Marx with a view to sorting out what is still valid, what can be cast off, and what needs to be rethought. Freudian theory is vulnerable to attack on many points, but not, in my opinion, on the one that formed The American Nightmare's psychoanalytic basis: the theory of repression and the "return of the repressed." We can all trace the workings of this, surely, in our own personal histories and daily lives; it continues to have great resonance in relation to the horror film...

Wood may over-emphasise the extent to which the mere unburdening of repression and the "return of the repressed" is at work in film spectatorship. Repression is just one form of defense explored in psychoanalytic theory. Nonetheless, Wood makes clear the idea that psychoanalytic insights into film are not an all-or-nothing, take-it-or-leave-it phenomenon. Getting clear about the way psychoanalysis may, on the one hand, share the stage with other interpretative methods and tools and, on the other, characterise some fairly general aspects of the spectatorship of genres (such as horror films) will be a task for our discussion of psychoanalysis and genre below. For now, it is worth pointing out the basic fallacy of rejecting any psychoanalytic theorising about film or interpreting films and film genres by problematising its blanket, universal application. For example, certain films - say a documentary on an economic crisis such as Craig Ferguson's Inside Job (2010) - seem neither

\footnotetext{
${ }^{9}$ See Pataki's (2014) account of wish-fulfilment and desire in philosophy and psychoanalysis.
} 
to invite nor reward psychoanalytic treatment (as opposed to the people depicted in the film, who surely do invite such treatment).

Prominent uses of psychoanalysis in film theory throughout the 1960s and 1970s tended to offer universal and fundamental analyses of the experience of film. Christian Metz (1982), for example, emphasised the "gaze" and its psychoanalytic significance. The idea is that the appeal of watching meaningful, moving images on a screen is based on an identification with the camera and corresponding fetishistic scopophilia. This is an essentialising move: a way of explaining the key features of all cinematic experience within a single theoretical perspective. This essentialising approach reached is apotheosis with 'apparatus theory' in the 1970s. Apparatus theory combined psychoanalytic, semiotic and Marxist theoretical perspectives in one theory-one that made the psychoanalytic and ideological character of film spectatorship an inevitable product of the physical and institutional apparatus of film production. (See Baudry, 1986.)

The attempt to construct an essentialist theory of cinematic spectatorship, one that characterises spectatorship of the moving image as such within one overarching theory, has largely been abandoned. This leaves open the possibility that psychoanalytic insights are an important and ineliminable framework to explain particular aspects of film spectatorship. Some writers, however, remain unconvinced of even this. ${ }^{10}$ For example, Richard Allen is largely critical of psychoanalytic approaches to film. He describes "[p]sychoanalytic theory [as] a theory of the relationship between sexuality and unconscious mental states..." (2009: 446) Part of the reason Allen is critical of psychoanalytic approaches to film is that he mischaracterizes and oversimplifies psychoanalytic theory. It is true that psychoanalysis is concerned with sexuality and unconscious mental states, but it is also misleading as a characterization generally, and especially as one that can adequately ground

\footnotetext{
${ }^{10}$ See Buscombe et al. (1975: 119; 125-6) for criticism of psychoanalytic approaches to film published in Screen, the leading academic journal for the study of film and television. "Our reservations are in three main areas: the unproblematic acceptance of psychoanalysis implicit in the way it has been presented in Screen; the intelligibility of the various expositions and applications of it; and the validity of the attempts made to apply it directly to the cinema" (119). The objections appear to amount to rejection of the validity of psychoanalysis in its entirety.
} 
the relevance of psychoanalytic theory to film. It mirrors the untutored idea, along with objections based on that idea, that psychoanalysis is all about sex. Not only does sexuality have to be interpreted broadly with reference to bodily and mental pleasures (not sex as ordinarily understood); but connections between sexuality and unconscious mental states have to be understood in relation to the orectic (i.e. to desire and appetite). If this is not done, then it is difficult to envision psychoanalytic film theory as even getting started.

Gabbard (2001:5-12), the first film review editor for the International Journal of Psychoanalysis, gives an exhaustive overview of psychoanalytic approaches to film, including the explication of underlying cultural mythology, the film as reflective of the film-maker's subjectivity, the film as reflective of a universal developmental moment or crisis, the application of Freud's dreamwork to film, the analysis of spectatorship, the appropriation of psychoanalytic constructs by the film-maker, and the analysis of character in the narrative. These overlap and are by no means mutually exclusive. Analysis of some films may require several approaches, and it should go without saying that psychoanalytic interpreters of film do not see themselves, and should not be seen as, employing the only useful approach to understanding character, narrative or spectatorship-not even when such an approach is thought of as necessary. As Gabbard (2001:12-14) says, Some psychoanalytic film critics deliberately mix methodologies for a more comprehensive reading of a particular text ... [When] A multiplicity of theoretical perspectives is brought to bear ... the result is a psychoanalytic film criticism that understands a particular movie as having multi-layered meanings that are not immediately apparent to the average viewer. Nor is it plausible to suppose that the perspectives are all psychoanalytic.

Much of the controversy in applied analysis has revolved around whether the appropriate subject for analysis is the art object itself or, rather, the biographical features of the artist that may contribute to our understanding of the forces shaping the artistic creation. Both may be fruitful subjects for exploration, and psychoanalytic film scholars have made productive use of both approaches. Obviously, when one applies a psychoanalytic lens 
to the text of a film, one cannot hope for a definitive reading. A more modest goal is to emphasise how psychoanalytic theory can often illuminate what appears to be happening on the screen and the manner in which the audience experiences it.

To sum up this discussion: psychoanalytic accounts of the nature and function of art and film should not be taken, as they often are by their critics, as reductive. Psychoanalytic accounts do not rule out other purposes, functions and explanations of art. These include the rational exploration of ideas and feelings as entertaining, as providing cognitive insights of various kinds, as morally examining the social, political and personal status quo.

\section{The Orectic Self: Psychoanalysis, Dreams, Film}

Psychoanalysis claims that psychic life is dominated by our orectic nature-that is, driven by desire and wish-fulfilment. We are not the rational, transparent self-knowing creatures we generally take ourselves to be. Art too is orectic. It functions, though not exclusively, to satisfy psychological needs of artists and audiences, and relates artists to the audiences in virtue of common desires and satisfying phantasies. Gabbard (2001:5-6) for example says

Just as dreams function as wish-fulfilments (at least in many cases), so do films provide wish-fulfilling solutions to human dilemmas. In the 1946 classic, Frank Capra's It's a Wonderful Life, for example, the post-World War II audience vicariously experienced the magical resolution of three pervasive internal conflicts: adventure/domesticity, individual/community and worldly success/ordinary life... the film does not so much resolve these anxieties as push them to one side... Audiences loved Capra's film, however, because its ending so completely disposed of what had briefly returned from the repressed.

Psychoanalysis sees these needs, desires and phantasies, along with the artist's often unconscious intentions, as necessary for interpreting film and for understanding spectatorship (e.g. spectator 
satisfaction). Such a view also provides grounds for psychoanalysis to see art as integral and necessary to living well.

Films function psychoanalytically in various other and related ways as well. Gabbard (2001:7) describes some films as "reflective of the film-maker's subjectivity...[as] a canvas in which the director attempts to work through and repair problematic childhood experience and conflicts." And again drawing on the likeness between dreams and film, he says (2001:8) that “Certain films defy conventional analysis and understanding unless they are viewed as dreams subject to condensation, displacement and other elements of Freud's dreamwork." Many of the films of Alfred Hitchcock are best understood in this way. For example, Vertigo (1958) casts its protagonist into a dream-like following of a phantasy object: its loss, its replacement and final loss at which exact point the protagonist's vertigo is cured. It is difficult to see how the film can be understood at all without deploying psychoanalytic categories of explanation.

The alleged connections and likenesses between dreams and film is often emphasised by psychoanalytic approaches and many are summed up in Allen's (2009: 448-9) account of McGinn (2005).

McGinn has explored the film-dream analogy ... plausibly noting the way that our familiarity with dreams tutors our experience of film ... Films, like dreams, are characterized by sensory/ affective fusion ... like dreams, they are characterized by spatial discontinuity and by temporal fixation .... are attention dependent ... are often characterized by a heightened sensation of movement that is linked to the solicitation of strong emotion... are characterized by the "salience" of every element, at once compressing information and amplifying emotional impact... [M]ost contentiously... McGinn claims that in films, like dreams, the minds of others seem peculiarly transparent to the spectator. The body or face in a dream is designed to express a given mind, in this sense it is a transparent portal to the mind in a way that the face of the other usually fails to be. Likewise in films, 
the human mind is not merely inferred from bodily criteria, but appears something we have transparent access to.

Allen (2009:450) also cites “...many disanalogies between dreams and watching a movie ... the most important of which is that the spectator is wide awake and the images are real (Metz 1982). The analogy ... at best provides a partial understanding of the film experience and an understanding that is probably not best cashed out in psychoanalytic terms."

The analogies between dreams and film spectatorship are nonetheless salient to understanding film spectatorship. Moreover, psychoanalytic comparison between dreams and film spectatorship is not pointing to a mere analogy between them, but to a common explanation of them in terms of psychic functioning. Most obvious here is the psychic defense against anxiety and corresponding wish-fulfilment of both dreams and film spectatorship.

\section{A Case Study: Science Fiction Disaster Films}

Let us consider an example of this: science fiction disaster films. In her seminal essay "The Imagination of Disaster," Susan Sontag (1965) argues that science fiction films from the 1950s and 60s (significantly, during the height of the Cold War) and viewers' attraction to them, should be seen as reflecting a widely held fear of catastrophe as well as ambivalence towards science, scientists, technology and politicians. The films display anxiety and worry about disaster, nuclear annihilation and the like, while at the same time providing easy wish-fulfilling answers to such anxieties. ${ }^{11} \mathrm{~A}$ basic claim of psychoanalytic theory is that dreams function in part to protect sleep. If this is right, there is a further analogy to be drawn between dreaming and film. The kinds of science fiction films Sontag discusses function so as to enable people to avoid confronting and consciously examining their

\footnotetext{
${ }^{11}$ Gabbard (2001:8) says "Part of the appeal of the horror and science fiction genres is related to the audience's vicarious mastery of infantile anxieties associated with earlier developmental crises. The audience can re-encounter terrifying moments involving early anxieties while keeping a safe distance from them and knowing that they can survive them."
} 
anxiety, as well as consciously considering strategies for dealing with real problems. ${ }^{12}$ They function, as it were, to keep us asleep.

It is no surprise that movies (some movies) have long been seen as forms of escapismincluding ones that do not, on the surface, appear as escapist. The films Sontag discusses, on her own account, really do aid and abet moral and existential escapism. Lest this sounds overly negative, it should be remembered that psychoanalytically speaking escapism of this kind is at times as necessary as it is desirable. Such escapism is generally desirable only temporarily as the real world will not indefinitely be put off. However, it is a mistake to think that one should or could permanently escape escapism, just as it is a mistake to think that, psychoanalytically speaking, complete self-transparency, or a life completely free of neuroses, is possible.

A good deal of what Sontag discusses has to do with catastrophe on a global scale; where what is being considered is the obliteration of earth or life as we know it on earth. One thing that Sontag's essay overlooks - perhaps because the films themselves do not deal with it, and given the way they function, could not deal with it-is the aftermath of catastrophe. That is, the rebuilding following extra-terrestrial invasion and devastation. What happens when the monsters are gone? The reason for such oversight is clear. Such films function, after all, to relieve rather than enhance anxiety and questions about what is to be done in the aftermath are surely anxiety producing.

Sontag says (1965: 224) "From a psychological point of view, the imagination of disaster does not greatly differ from one period in history to another. But from a political and moral point of view, it does." On this view, the imagination of disaster does not change because psychologically speaking, neither the precipitating concerns and fears (death, loss of love, meaninglessness), nor the ways in which people's minds endeavour to assuage them, substantively differ from disaster to disaster. ${ }^{13}$

\footnotetext{
${ }^{12}$ Sontag discusses many films. They include War of the Worlds (1953), Conquest of Space (1955), This Island Earth (1955), The Mysterians (1957), The Day the Earth Caught Fire (1962).

${ }^{13}$ It is a common mistake to think this ahistoricity excludes a sensitivity to context. Schneider (2004:11-12) takes up this issue of historicity in discussing Crane (1994) and Tudor (1997). He writes: "Jonathan Lake Crane... charges those theorists who offer depth-psychological explanations of canonical horror film monsters and
} 
Although science fiction films are "strongly moralistic"(1965: 216), Sontag notes that they contain "absolutely no social criticism of even the most implicit kind ... No criticism... of the conditions ... which create the impersonality and dehumanization which science fiction fantasies displace onto the influence of an alien It" (1965: 223). Why the lack of critical concern? Sontag's account of the function of these films carries an implied explanation. Serious social criticism is not merely beside the point, but would also prevent the films from providing the satisfactions audiences seek. Though the satisfactions are largely psychological, they may serve to emotionally ground specific beliefs and, more broadly, one's cognitive outlook-one's understanding of reality-on the social, political and personal status quo. By their very nature, the science fiction films Sontag discusses cannot concern themselves with serious social or political criticism, even though they may express it. Any serious questioning of the moral and political status quo-conditions that are responsible for the disasters befalling people-would hamper the operation of phantasy and its production of temporarily satisfying "solutions" to whatever catastrophe is being depicted. ${ }^{14}$ Of course, it is possible that science fiction films offer serious social and philosophical reflection. Andrei Tarkovsky's Stalker (1979) is a philosophically rich post-disaster film. It follows three men-a scientist, a writer and their guide, the stalker of the title-as they plot their way through a forbidden zone, the site of a mysterious disaster. However, films such as this are not typical of the science fiction genre and do not generally capture the attention of science fiction fans. Tarkovsky's film is first and foremost an art film, not a science fiction film.

narratives ... with ahistoricity: 'In irrevocably linking horror to the unconscious we dismiss, all too hastily, the possibility that horror films have something to say about popular epistemology, about the status of contemporary community, or about the fearsome power of modern technology' (Crane 1994: 29)." But the psychoanalytic linking of horror to the unconscious entails no such dismissal. On the contrary, psychoanalysis supports all of Crane's claims with a variety of explanatory theses. Similarly, Schneider (2004:12) notes that "Tudor finds fault with those 'universalizing' explanations of the pleasure viewers get from watching horror films on the grounds that it is only possible to speak of the appeal of a genre in a particular sociotemporal context. ... [P]sychoanalytic models, arguably already reductive, will be particularly misleading, conceptually inclined to neglect the variability of audience responses in the name of a spurious generality'(1997: 456)." This misunderstanding was addressed above.

${ }^{14}$ See Levine and Taylor 2012; 2013. 


\section{Cognitivist Rejection of Psychoanalytic Film Theory}

As noted in the introduction, cognitivists attempt to explain basic features of film experience using the resources of contemporary cognitive science and analytic philosophy, selfconsciously eschewing the work of psychoanalytic theorists. Without recourse to psychoanalytic concepts and ideas, they attempt to explain such things as the identification audiences succeed in making with film protagonists; how audiences are able to follow the plot of films, given the gaps in narrative and shifting perspectives characteristic of most films; and whether the moving image is an illusion or not.

The cognitivist film theorist Noël Carroll offers one of the most sustained and trenchant criticisms of psychoanalytic approaches to film $(1988,1990,1996,2004 b)$. His championing of a cognitivist turn in film studies has been so successful that such approaches have come to be seen as incompatible with psychoanalytic approaches. However, this is only the view from the cognitivist side. The key questions of cognitivist film theory differ from, but do not replace, the key questions of psychoanalytic approaches to film. In this section, we set out what is at issue in the debate between cognitivist film theorists and psychoanalytically informed film theorists.

There are two key psychoanalytic claims that cognitivists by and large take issue with. First, things such as narrative curiosity are not primarily, let alone exclusively, capable of explaining the pleasures of spectatorship. Second, these pleasures require psychoanalytic interpretation. If the psychoanalytic account of the mind and psychic life is broadly correct, then its interpretation of the pleasures of cinematic spectatorship is broadly correct too. On a psychoanalytic account it is, for example, no more possible to explain prejudices as cognitive mistakes (e.g. "people of colour are lazy; Jews are lascivious"), rather than in terms of ego-defense, than it is to explain the attraction to horror film in cognitive terms while ignoring our orectic natures.

Cognitivist criticism of psychoanalytic approaches to film is based partly on scepticism about the credentials of psychoanalysis as a theory of mind and partly on a mistaken essentialism. We discuss this scepticism below, but first let us consider the essentialist presupposition of the 
cognitivists. We mentioned above certain essentialising forms psychoanalytic film theory has taken in the past. We claimed that this tendency to produce an essentialising theory of the cinema reached its most extreme form in 'apparatus theory', the theory prominently advanced by Jean-Louis Baudry and based on the claim that the apparatus of cinema-the means of the production of cinematic experience-is essentially a psychoanalytically explicable process. Interpreted as a totalizing account of the possibility of cinematic experience, apparatus theory suffers from theoretical overreach. However, it seems plausible to say that the cognitivists' mistake is to over-react to this and substitute an overreach of their own. Psychoanalytical insights into cinematic experience are not limited to grand theories such as apparatus theory; and if psychoanalytic accounts of the orectic nature of our psychic lives, in the cinema and out of it, have any merit, then we should expect highly context-laden and partial explanations of cinematic experience to emerge from it. Cinematic experience, its pleasures and its dreads, will necessarily depend upon the peculiarities of the subject and the subject's psychological history and character. One-size-fits-all theories of cinematic experience run counter to the fundamental claims of psychoanalytic theory.

However, this does not rule out the possibility of quite general claims being made about genre and the nature of the filmic experiences elicited by a genre. Genres are characterised by a commonality of experience as well as structure and narrative. Typically, we go to a musical film (whether La La Land (2016) or Meet Me in St Louis (1944)) for a certain kind of experience: musical pleasure, escapist entertainment, the aesthetic joy of watching people who can dance, dance. The goal, therefore, of psychoanalytic explorations of genre is to understand the typical experiences of typical audience members in typical films of the genre. There is a lot a room in this for exceptions of all kinds; and it is compatible with a realisation that there may be not one kind of typical audience member or not one kind of typical filmic experience of genre. Proffered psychoanalytic explanations are not essentialising about genre, but are fairly general in their explanatory ambitions nonetheless.

For several reasons, the best genre for contrasting psychoanalytic and cognitivist approaches to cinema is the horror genre. On the one hand, it presents an apparent paradox - the so- 
called paradox of horror - which is fertile ground for psychoanalytic insight. (The paradox of horror is simply the question of why horror films generate audience pleasure from negative emotions of fear and disgust.) The horror genre appears highly suited to psychoanalytical explanation as, for a psychoanalytically orientated film theorist, the horror genre presents a striking insight into the nature of cinematic phantasy. On the other hand, the genre has been the site of robust cognitivist attempts to do away with psychoanalytic explanation and replace it with narrative based explanations. (Very roughly: audiences enjoy watching horror films because they want to know what happens when a monster is let loose. Why? Because they find the idea of it interesting; their curiosity has been piqued.) If the cognitivist rejection of psychoanalytic approaches to film is to gain real purchase, it will be in virtue of the fact that the cognitivists can show psychoanalytic explanations of the experience of horror films to be either wrong-headed or entirely superfluous. ${ }^{15}$

\section{Cognitivist and Psychoanalytic accounts of Horror}

Noël Carroll is the chief architect of this cognitivist take on horror film experience. ${ }^{16}$

Carroll's account of the (ir)relevance of psychoanalysis to horror films contrasts very nicely with Schneider's account (2000). Carroll (2004b: 263) says "Schneider points out that in Freud's [1919] characterization of the uncanny, which he finds useful for modeling horror, Freud indicates that not only repressed wishes, but also [the reconfirmation of] surmounted beliefs, can function to trigger the sense of uncanniness ([Schneider] 2000: 172). These surmounted beliefs include things like infantile beliefs in the omnipotence of the will and the belief that the dead can return to life." The "return of the repressed"

\footnotetext{
${ }^{15}$ See Levine (2004) for a response to criticisms of psychoanalytic film theory's approach to horror.

${ }^{16}$ Carroll 1990.
} 
temporarily satisfies certain wishes and desires and, according to Schneider, partly explains our attraction to horror. ${ }^{17}$

Schneider also discusses an aspect of the uncanny in relation to horror-a favourite of Alfred Hitchcock's - known as "Doubling." ${ }^{18}$ Perhaps the most striking example of doubling in Hitchcock's oeuvre occurs in Shadow of a Doubt (1943). In that film, Hitchcock tells the story of two Charlies: a killer, played by Joseph Cotton, and his favourite niece, Charlotte (Charlie), played by Teresa Wright. The two play off each other, with parallel and opposing narrative paths. The effect lends a sense of the uncanny to a story that would otherwise be fairly routine.

Carroll concedes the fact that psychoanalysis might be interpretatively relevant because it influences the way in which artists and audiences frame their self-understanding. He calls this a hermeneutical defense of psychoanalytic interpretation. ${ }^{19}$ However, this hermeneutical defense does not go very far. He writes (2004b: 259; cf. Carroll 1990): "This defense of the relevance of psychoanalysis to the horror film, however, does not entail that psychoanalysis is relevant to the interpretation of all horror films. For, pervasive though psychoanalytic thought may be, it is not the case that in every horror film one will find evidence of psychoanalytic concepts, scenarios, and/or imagery." And again Carroll (2004b:260-1) says "I agree that many horror films deserve a psychoanalytic interpretation

\footnotetext{
${ }^{17}$ See Schneider 1997; 2000 for an explanation of how (i) the "return of the repressed," and (ii) the reconfirmation of previously surmounted infantile beliefs addresses the question of the attraction of horror. Schneider also explains - again in terms of the above- why certain kinds of monsters and horror films lose their appeal and fail to frighten by failing to evoke the "uncanny."

18 "A Doppelganger ("double walker" in German) is a double or second-self. In literature, dream analysis, or archetypal symbolism, the Doppelganger is often figured as a twin, shadow, or mirror-image of the protagonist. The Doppelganger characteristically appears as identical (or closely resembling) the protagonist; sometimes the protagonist and the Doppelganger have the same name."

Glen Johnson: http://faculty.cua.edu/iohnsong/hitchcock/pages/doubles/doppelgangers.html retrieved 24/06/2016.

${ }^{19}$ It should be noted that what Carroll calls the "hermeneutical approach" is not what is generally meant by a hermeneutical approach (e.g., compare it with Paul Ricoeur's account), but is instead a simple form of contextualism. Psychoanalysis can be and is used hermeneutically, but not generally in the ways that Carroll claims it can be appropriately used. The ways Carroll thinks appropriate are indifferent to the truths of psychoanalysis. They are based only on explicit and implicit authorial intent, but not intent as psychoanalytically interpreted.
} 
(at least in part), [but] they [psychoanalytic critics] believe that all horror films should be interpreted psychoanalytically." But there is no reason to insist that psychoanalysis is relevant to all horror films. As we have emphasised previously, it is enough if psychoanalysis is relevant to typical films of the genre and typical genre-audiences.

The reason those in favour of a psychoanalytic approach would reject Carroll's "hermeneutical defense" is not because they think all horror films require psychoanalytic interpretation. ${ }^{20}$ They reject it because as characterized by Carroll it is beside the point for the kind of psychological explanations of spectatorship and interpretation of films that psychoanalytically informed theorists and interpreters seek. Perhaps Carroll would agree. He says (2004b: 260-1) says "One reason why many psychoanalytic critics are apt to reject what I've called the hermeneutical defense of their practice is that they believe that psychoanalysis is true, whereas the preceding hermeneutical defense does not require that psychoanalysis be any less wacky than scientology to be apposite in a given case." ${ }^{21}$ This gets closer to why psychoanalytically orientated critics reject Carroll's hermeneutic defense. Carroll's disdain is palpable and it is clear that the rejection of psychoanalytic approaches to film frequently rests on a wholesale rejection of psychoanalysis itself. ${ }^{22}$

\footnotetext{
${ }^{20}$ Schneider (2004:11) puts the point in this way: Just as "one should not assume, prima facie, that either Freudian psychology or one singular version of psychoanalytic theory is the key to understanding a text" (Allen 1999: 142), one should not assume that any version of psychoanalysis, not even any combination of versions, is the key to understanding every horror text. Most critics object to what they perceive as psychoanalytic horror film theory's unsupportable claims of explanatory sufficiency. This objection appears in a number of forms and cuts across the distinction I have been drawing between a minimal, epistemically neutral use of psychoanalytic theory and a use of such theory which depends on the truth of at least some of the particular version's substantive theses.

${ }^{21}$ See Hopkins (1988) and Levine (2004:35-40) for a critique of the claim that psychoanalysis is unfalsifiable.

${ }^{22}$ Stephen Prince (1996: 72-73) states that "the primary and to my mind insurmountable problem with basing general theories of spectatorship on psychoanalysis is that such theories must remain unsupported because psychoanalysis is a discipline without reliable data." Prince endorses Colby and Stroller (1988: 3, 29), who claim that "psychoanalytic evidence is hearsay, first when the patient reports his or her version of an experience and second when the analyst reports it to an audience... Reports on clinical findings are mixtures of facts, fabulations, and fictives so intermingled that one cannot tell where one begins and the other leaves off". See Levine (2004) for a critique of these claims.
} 
Carroll (2004b: 261) says “... the case for explicating all horror films

psychoanalytically will depend on showing that there is something in the very nature of the horror film that is peculiarly suited for psychoanalysis. That is, the psychoanalyst needs to establish that there is something in the essence of horror-something without which a film would not be a horror film — that is only explicable or that is best explained psychoanalytically." Yet one can easily drop the claim that horror film "is only [and exclusively] explicable" in psychoanalytic terms, and still claim that horror films are largely "best explained psychoanalytically."

Tudor (1997: 449) challenges just this claim. The psychoanalytic explanation of the pleasures associated with horror in terms of the return of the repressed, e.g. as offered by Schneider, are inadequate. He says that "it is necessary to pose supplementary mechanisms to bridge the gap between a general account of repression and the specific explanation of pleasure, and these supplementary mechanisms lead away from the pure form of the repression model." But such supplements will be part of any more complete explanation of the attraction of horror in terms of the return of the repressed. Unsurprisingly, there are various and often-conflicting accounts of what additional elements are needed to explain the attraction of horror. Thus, Kristeva's notion of "abjection," taken up by Barbara Creed in her (1993) theorization of the "monstrous-feminine" in terms of a Lacanian account of the "Real" and the construction of the feminine as "Other," seeks to give a more complete explanation of the attraction of horror. ${ }^{23}$ The extent to which these notions, and Lacanian psychoanalysis generally, are compatible with what Freud says about horror and Freudian theory in general, is controversial. But psychoanalytically informed elaborations on the return of the repressed, if evidentially defensible, support rather than subverts this model.

Although Tudor regards recourse to additional explanation in terms of psychoanalytic theory as ad hoc, it need not be. In psychoanalysis as elsewhere, more complete explanations require

\footnotetext{
${ }^{23}$ Tudor (1997:450) cites The Exorcist, Carrie, Alien, The Brood, and The Hunger as examples of films in which the monstrous-feminine "does play an important role." It is unclear why he makes this claim given his apparent rejection of feminist film theory that employs "structural psychoanalysis."
} 
additional detail. The return of the repressed may be pleasurable for a variety of reasons depending on the repressed element and depending also on the particular spectator. The pleasures of horror, dependent as they are upon the effects of the repressed, may involve substitutive satisfactionsmuch like neurotic activity which provides replacement satisfaction for something that did not occur. $^{24}$

Carroll (2004b: 264) appears to back away from his claim that psychoanalysis is not important to interpreting some films and aspects of spectatorship beyond the false friend of his hermeneutical defense. He says

that psychoanalysis might not be applicable to all horror films does not entail that it cannot clarify some. Psychoanalysis is a vast and complex body of ideas, including not only meta-psychological theories but also observations of hithertofore scarcely noticed patterns of human behavior. Some of these ideas, if they are well founded and if they track the phenomena on the screen, may illuminate otherwise perplexing aspects of particular horror films.

Carroll's rejection of psychoanalytic approaches dwindles here to the question of just how illuminating, relevant and sometimes necessary psychoanalytic approaches are-rather than whether they are relevant at all. He appears willing to accept some psychoanalytic observations and insights, but not the theory that explains or supports them. In any case, the concession is short lived. He continues (Carroll 2004b: 266) "My own suspicion... is that where most psychoanalytic interpretations of horror films succeed, it is on historicist grounds, but that may only reflect my skepticism about how many well-founded, uniquely psychoanalytic observations there are to be had about recurring patterns of human behavior..." In other words, where psychoanalysis is relevant and succeeds with regard to explaining horror (or anything else), its successes are likely to be rare. Where psychoanalysis does appear to explain features of the experience of art horror, it is unlikely

\footnotetext{
${ }^{24}$ See Hopkins' (1982: xxi) discussion of the table cloth lady.
} 
to be uniquely insightful. That is, it is likely to be based on observations available from other psychological perspectives. Psychoanalysis is largely otiose.

A problem with Carroll's discussion here is his reduction of psychoanalytic explanation to the observation of recurring patterns of behaviour. As we have argued above, psychoanalysis is also an orectic mode of explanation. Its explanatory power rests, in part, on the idea that our pleasures are often based on desires that are hidden from us or disguised for us. Carroll's attempt to direct the attention of film scholars away from engaging with psychoanalysis is, in the end, based on a general theoretical hostility to psychoanalysis. It is not based on any well-developed insights into the nature of film, the moving image, cinematic spectatorship and the like.

\section{Conclusion}

Psychoanalytic approaches to film have focussed on genres like horror, along with feminist critiques of aspects of spectatorship like voyeurism and misogyny that seem to cry out for psychological explanation. Psychoanalysis also played an important role in the emergence of grand theories of film in the 1970s, theories such as 'apparatus theory'. We have argued that the most significant contribution of psychoanalysis to the understanding of film is not made through such grand theories of film, but through the explanation of certain pervasive and striking features film spectatorship, including the spectatorship of individual films and typical examples of genre films.

\section{References}

Allen, R. (2009). "Psychoanalysis." The Routledge Companion to Philosophy and Film, 445-456. Edited by Paisley Livingstone and Carl Plantinga.

Allen, R. (1999). "Psychoanalytic Film Theory." A Companion to Film Theory, ed. Toby Miller and Robert Stam. Oxford: Blackwell, 123-45. 
Baudry, J. L. (1986) [1970]) "Ideological Effects of the Basic Cinematographic Apparatus.” In P. Rosen (ed.) Narrative, Apparatus, Ideology, New York: Columbia University Press.

Bordwell, D. (1985). Narration in the Fiction Film. Madison, WI: University of Wisconsin Press

Bordell, D. and Carroll, N. (eds). (1996) Post-Theory: Reconstructing Film Studies. Wisconsin: University of Wisconsin Press

Buscombe, E; Gledhill, C.; Lovell, A.; Williams, C. (1975). "Statement: Psychoanalysis and Film." Screen 16 (4): 119-130. doi:10.1093/screen/16.4.119

Carroll, N. (2004a). "The Power of Movies" in Peter Lamarque and Stein Olsen (eds) Aesthetics and the Philosophy of Art: The Analytic Tradition. Oxford: Blackwell, 485-97.

Carroll, N. (2004b). "Afterword: Psychoanalysis and the Horror Film," 257-270. In Steven Schneider

Carroll, N. (ed.) (2004). The Horror Film and Psychoanalysis: Freud's Worst Nightmares. Cambridge:

Cambridge University Press.

Carroll, N. (1999). "Art, Narrative, and Emotion," in Emotion and the Arts, ed. Hjort and Laver. New York: Oxford University Press.

Carroll N. (1996). Theorizing the Moving Image. Cambridge: Cambridge University Press.

Carroll, N. (1990). The Philosophy of Horror: or Paradoxes of the Heart. New York and London: Routledge.

Carroll, N. (1988). Mystifying Movies: Fads and Fallacies in Contemporary Film Theory. New York: Columbia University Press.

Clark, P. and Wright, C. (1988) (eds.). Mind, Psychoanalysis and Science. Oxford: Blackwell.

Clover, C. (1992) Men Women and Chainsaws: Gender in the Modern Horror Film. Princeton, N. J.: Princeton University Press.

Colby, K. M. and Stroller, R. J. (1988). Cognitive Science and Psychoanalysis. Hillsdale, N.J.: Lawrence Erlbaum.

Copjec, J. (1989) "The Orthopsychic Subject: Film Theory and the Reception of Lacan," October 49, pp. 53-71.

Crane, J. (1994). Terror and Everyday Life: Singular Moments in the History of the Horror Film. London: Sage.

Creed, B. (1993). The Monstrous-Feminine: Film, Feminism, and Psychoanalysis. London and New York: Routledge.

Currie, G. (1995). Image and Mind: Film, Philosophy, and Cognitive Science. Cambridge: Cambridge University Press.

Freud, S. (1953-74). The Standard Edition of The Complete Psychological Works of Sigmund Freud. J. Strachey, trans. and ed. London: Hogarth Press.

Freud, S. Three Essays on the Theory of Sexuality (1905d). S.E. VII, 123-243.

Freud, S. The Interpretation of Dreams (1900a). S.E. vols. 4-5.

Freud, S. "Creative writers and day-dreaming" (1908e [1907]). S.E. vol. 9, 141-154.

Freud, S. "On the Universal Tendency Towards Debasement in the Sphere of Love. (Contributions to the Psychology of Love)" (1912). S.E. vol. 11.

Freud, S. Introductory Lectures on Psychoanalysis. (1916-17). S.E. vols. 16-17.

Freud, S. "Mourning and Melancholia."(1917e). S.E. vol. 14.

Freud, S. "'A Child is Being Beaten': A Contribution to the Study of the Origin of Sexual Perversion" (1919a). S.E. vol. 17.

Freud, S. "The Uncanny" (1919b). S.E. vol. 17.

Freud, S. "Fetishism" (1927). S.E. vol. 21, pp. 147-157.

Freud, S. (1997). Writings on Art and Literature. W. Hamacher \& D. Wellbery (Eds.). Stanford, CA:

Stanford University Press.

Gabbard, G. (2001). "Introduction.” Psychoanalysis \& Film, Geln Gabbard (ed.). International Journal of Psychoanalysis Key Papers Series, Series editor Paul Williams, Karnac: London and New York, 116. 
Gabbard, G. and Gabbard, K. (1987). Psychiatry and the Cinema. Chicago: University of Chicago Press.

Gabbard, G. and Gabbard, K. (1999). Psychiatry and the Cinema. Washington, D.C.: American Psychiatric Press. $2^{\text {nd }}$ edition.

Hopkins, J. (1988). Epistemology and depth psychology: critical notes on The foundations of psychoanalysis. In: C. Wright, \& P. Clark (Eds.), Mind, Psychoanalysis and Science. (pp. 33-60). Oxford: Blackwell.

Hopkins, J. (1982). Introduction: philosophy and psychoanalysis. In: R. Wollheim, \& J. Hopkins (Eds.), Philosophical Essays on Freud, (pp. vii-xlv). Cambridge: Cambridge University Press.

Kaplan, E. A. (ed.) (1990). Psychoanalysis and Cinema. London: Routledge.

Kaplan, E. A. (1990). “From Plato's Cave to Freud's Screen.” In Kaplan, E. Ann (ed.) 1990.

Kemp, Gary \& Gabriele Mras (eds.) (2016). Wollheim, Wittgenstein, and Pictorial Representation: Seeing-as and Seeing-in. Routledge: London and New York.

Lacan, J. (1977). "The Mirror Stage as Formative of the Function of the I as Revealed in Psychoanalytic Experience." Ecrits: A Selection, trans. Alan Sheridan. London: Tavistock, 1-23.

Levine, M. (2016). "Wollheim's Ekphrastic Aesthetics: Emotion and its Relation to Art," in Kemp and Mras, 241-267.

Levine, M. (2015). “Freud's Aesthetics: Artists, art and psychoanalysis." In Simon Boag (ed.) Psychoanalysis and Philosophy of Mind. London: Karnac, 2015, 137-162.

Levine, M. and Taylor, W. (2013). "The Upside of Down: Disaster and the Imagination 50 Years On." M/C Journal: A Journal of Media and Culture. Catastrophe issue. http://journal.mediaculture.org.au/index.php/mcjournal

Levine, M. and Taylor, W. (2012). "War as Catastrophe: Jacques Callot's 'Miseries of War' as Moral Meditation." Journal of Art Theory and Practice,157-184.

Levine, M. (2004). "A Fun Night Out: Horror and Other Pleasures of the Cinema." In Steven Schneider (ed.), The Horror Film and Psychoanalysis: Freud's Worst Nightmares. Cambridge: Cambridge University Press, 35-54.

Levine, M. (2004). Racism in Mind, M. Levine and Tamas Pataki (eds.). Ithaca: Cornell University Press.

McGinn, C. (2005). The Power of Movies, New York: Pantheon.

Metz, C. (1982). The Imaginary Signifier: Psychoanalysis and Cinema, trans. C. Britton, A. Williams, B. Brewster, and A. Guzetti, Bloomington: Indiana University Press.

Mulvay, L. (1989). Visual and Other Pleasures, Bloomington: Indiana University Press.

Pataki, Tamas (2014). Wish-Fulfilment in Philosophy and Psychoanalysis: The Tyranny of Desire. London and New York: Routledge.

Plantinga, C. (2009). Moving Viewers: American Film and the Spectator's Experience. Berkeley, CA: University of California Press.

Prince, S. (1996). "Psychoanalytic Film Theory and the Problem of the Missing Spectator." In Bordell, D. and Carroll, N. (eds). (1996), pp.71-86.

Radford, C. (1977). "Tears and Fiction." Philosophy 52, pp. 208-213.

Ray, R. B. (1985). A Certain Tendency of the Hollywood Cinema, 1930-1980. Princeton, NJ: Princeton Univ. Press.

Rodowick, D. N. (1991) The Difficulty of Difference: Psychoanalysis, Sexual Difference and Film Theory. New York: Routledge.

Schneider, S. J. (ed.). (2004). The Horror Film and Psychoanalysis: Freud's Worst Nightmares. Cambridge: Cambridge University Press.

Schneider, S. J. (2004). 'Introduction: Psychoanalysis in/and/of the Horror Film.' In Schneider, ed. (2004), 1-15.

Schneider, S. J. (2000). "Monsters as (Uncanny) Metaphors" Freud, Lakoff, and the Representation on Monstorsity in Cinematic Horror." Horror Film reader, ed. Alain Silver and James Ursini. New York: Limelight Editions, 167-91. 
Sklarew, B. (1999). "Freud and film: encounters in the weltgeist." J. Amer. Pyschoanalytic Assn., 47: 1239-1247.

Smith, M. (1995). Engaging Characters: Fiction, Emotion and the Cinema. Oxford: Oxford University Press.

Sontag, S. (1979) [1965]. "The Imagination of Disaster." In Against Interpretation and other Essays, 209-225. New York: Dell

Sterba, R. (1940). The problem of art in Freud's writings. The Psychoanalytic Quarterly, 9: 256-268.

Studler, G. (1985) "Masochism and the Perverse Pleasrues of the Cinema" in B. Nichoals (ed.) Movies and Methods, vol. 2. Berkeley: University of California Press.

Tudor, A. (1997). "Why Horror? The Peculiar Pleasures of a Popular Genre." Cultural Studies 11, 44363.

Wolfenstein, M. \& Leites, N. (1950). Movies: A Psychological Study. Glencoe, IL: Free Press. Wood, R. (2004). "Foreword: "What Lies Beneath?" In Schneider (ed). 2004, xiii-xviii.

Žižek, S. (1991). Enjoy Your Symptom! Jacques Lacan in and out of Hollywood. New York: Routledge. 